\title{
FUTURE IMPERFECT \\ The youth and participation in the 2009 \\ South African elections
}

\section{Ebrahim Fakir, Zandile Bhengu and Josefine K Larsen}

\author{
Ebrahim Fakir is manager for governance, institution and processes at EISA \\ e-mail: ebrahim@eisa.org.za \\ Zandile Bhengu is serving an internship at EISA \\ e-mail: Zandile@eisa.org.za \\ Josefine $\mathrm{K}$ Larsen is a researcher at EISA \\ e-mail: Josefine@eisa.org.za; j.kuehnellarsen@googlemail.com
}

\begin{abstract}
It was widely believed that more young people would participate in the 2009 general elections than had participated in elections in the past. This conjecture was based on increased youth registration figures at certain points in the registration process. Since 2007/2008 there had been an intense focus globally on the historic election of Barack Obama as the first African American president of the United States and it was surmised that his victory would invigorate an interest in politics around the world. The Obama election campaign's extensive use of new media technologies, as well as the crafting of his central campaign message to appeal to the twin ideas of hope and change were thought to have had an invigorating impact on political idealism, political activism and political participation. This, along with other factors, it is widely claimed, had an effect on political and electoral participation in South Africa, especially among the youth. This article investigates these claims and examines trends in the participation of the youth in the four general elections held in South Africa since 1994, with a specific focus on the 2009 elections.
\end{abstract}

\section{INTRODUCTION}

Many researchers, commentators and analysts, as well as the Electoral Commission of South Africa (IEC) itself, expected more young people to participate in the 2009 elections than had done in previous elections. Indeed, many pronounced after the election that that had been the case. Yet the facts may point to conclusions 
that defy what appears to have become conventional wisdom. This article investigates the veracity of claims that youth interest and participation in the 2009 elections increased dramatically and examines trends in elections past and present.

It does so first by considering the demographic that constitutes the 'youth' and the numbers of young people eligible to vote compared to those who actually registered to vote. It is only on the basis of such comparisons that it is possible to draw relatively safe conclusions about the rate and depth of youth participation in elections and the trends over time.

Whatever the eventual turnout of the youth segment in 2009 it is true that young people registered in unprecedented numbers, signalling an interest in participating in the formal process of democratic decision-making through elections. However, data derived from tertiary institutions and data about membership of trade unions and voluntary associations present a slightly different picture - levels of participation in elections for student councils, clubs and societies are, in fact, quite low. This may be an early indicator of a level of social differentiation among young South Africans. Those who are relatively privileged because of their access to education and upward social mobility might be opting out of political and electoral processes because those processes are perceived to be inefficient, passé and ineffective in catering to the needs of such a constituency. Those who are relatively less privileged (or those who are privileged but rely on political connections for business and access to goods and services) are still keenly interested in the political process as it brings access to goods and services which they would not get were they not an intrinsic part of the political process.

In addition to the fact that socio-economic differentiation shapes political participation, racial cleavages also have an impact on political participation among the youth.

[There are] significant racial differences in attitudes within the younger generation, with black youth expressing more positive attitudes or 'democratic enthusiasm' than other population groups towards voting. The most distinct difference in the intention to vote is between young black respondents aged $18-29$ of whom $67 \%$ intend to vote and $43 \%$ of similarly aged in other population groups.

Roberts \& Letsoalo 2009, p 12

On 22 April 2009 South Africans voted in the country's fourth democratic, nonracial election. Many interesting events that prefigured the election may have had a significant impact on the country's socio-political dynamics. The country's president, Thabo Mbeki, had been voted out of office as African National Congress 
(ANC) president and, just eight months before his term of office as head of state had come to an end, had, at the request of the party, stepped down as head of state.

His resignation was followed by the formation of the Congress of the People (Cope) led by Mosiuoa Lekota, former national chairperson of the ANC, and Mbhazima Shilowa, former Gauteng premier, both former members of the national executive committee of the ANC. The newly elected president of the ANC, Jacob Zuma, was acquitted on long-standing criminal charges just weeks before the elections. The ruling party and its allies, the Congress of South African Trade Unions (Cosatu) and the South African Communist Party (SACP) were riven with ideological and personal political differences and tensions and the pre-election buildup was characterised by a spate of (sometimes violent) protests. Notwithstanding these factors, and although the ANC's two-thirds majority was reduced, the election confirmed the dominance of the party nationally, although the opposition Democratic Alliance (DA) displaced it in the Western Cape.

In the international context, the United States of America experienced something of a revolution in its own society when it elected an African American president. In his election campaign Barack Obama introduced a new style of campaigning, with a substantial focus on attracting the votes of young people. The use of technology, especially social networking sites, in order to reach out to the youth holds important lessons for both developed and developing democratic societies. The enthusiasm generated by the Obama campaign and his subsequent election may have spurred a greater interest in politics among the youth in South Africa, and possibly worldwide, not just because of the use of technological platforms that appeal to young people but because the campaign message and the inculcation of a style and type of politics that placed the youth at the centre of social and political change attracted them.

This article seeks to explore the factors behind the apparent high youth voter turnout in South Africa in 2009, with the understanding that South Africa's youth have been and continue to be politically active, beyond participation in elections. A comparison of data on population growth, the number of young people eligible to vote, and the number who registered allows us more properly to consider the seemingly glib pronouncements that the youth demonstrated an interest and participated in large numbers in the 2009 election.

Examination of these data will also allow us to make a few preliminary and generalised findings about some trends and assist us to identify what will be required to sustain the involvement of those who are participating in elections and attract the participation of those who are not. In the process we will examine the extent to which the Obama campaign, and Obama's subsequent election, influenced the South African youth vote. 


\section{YOUTH POPULATION: PROBLEMS OF DEFINITION}

The varying definitions of the term youth inevitably affect any discussion of the topic. In 2000 the United Nations defined youth as 'anyone ranging in age from 15 to 24 years' (United Nations 2000). The Independent Electoral Commission of South Africa, for the purposes of the 2004 elections, categorised youth as people between the ages of 18 and 35 (IEC 2005, p 10) but redefined the age range prior to the 2009 election to 15-29. In the National Youth Act of 1996 youth are defined as persons in the age group 14 to 35 years and it is this age bracket that is acknowledged in the National Youth Policy for 2008-2013. For the purposes of this paper the age group 15 to 34 will be used. This includes teenagers aged between 15 and 17 who are not eligible to vote since the voting age in South Africa is 18. The non-standardisation of demographic categorisations creates significant difficulties with generating comparative analyses.

Because of this lack of consensus the numbers and statistics used in this paper may not reflect accurately the actual number of young South Africans who are eligible to vote. Thus, in comparing youth voter turnout in the 1999, 2004 and 2009 national elections it is necessary to be careful when drawing definitive conclusions about the number of eligible young voters, compared to the numbers who registered. These data are critical if we are to draw appropriate conclusions about the participation of young people.

Many developing countries, including South Africa, have young populations because of recent decades of high fertility along with improvements in child survival rates. Indeed, of the 40.6 million South Africans enumerated in 1996, 16.1 million (40\%) were people in the age bracket 14 to 35 (Statistics South Africa 2001). Statistics South Africa (StatsSA) recorded an estimated population of 49.3 million in 2009 as per medium variant (StatsSA 2009), of whom 15.5 million (31\%) were in the age group 15-34 (StatsSA 2009). The proportion of youth thus decreased by 9 per cent between 1996 and 2009, however the statistics reveal that South Africa's population is still very young. Consequently, a high number of young people would be expected to register to vote, although this does not indicate that the percentage of youth participating in elections has increased.

Table 1

Registered voters

\begin{tabular}{|l|r|r|r|r|r|}
\hline Age band & $\mathbf{1 9 9 9}$ & $\mathbf{2 0 0 0}$ & $\mathbf{2 0 0 4}$ & $\mathbf{2 0 0 6}$ & $\mathbf{2 0 0 9}$ \\
\hline $\mathbf{1 8 - 2 9}$ & 5834918 & 5361326 & 5877131 & 5492072 & 6283630 \\
\hline All registered & 18172000 & 1847200 & 20674926 & 21054957 & 23174279 \\
\hline
\end{tabular}

Source: IEC South African Voter Registration Case Study 24 October 2007 
As Table 1 shows the IEC recorded a total of 18.1 million South Africans registered ahead of the 1999 general election, 20.6 million for the 2004 elections and more than 23 million for the 2009 elections. In 2009, according to the IEC, 'about 27\% of the total registered voters were constituted of youth voters' ${ }^{1}$

Statistics of registration of young people aged between 18 and 29 show an increase. In 2009, 6.3 million young people were registered, whereas in 2004 and 1999 the figure was 5.8 million. ${ }^{2}$ In 2004 the Chief Electoral Officer, Advocate Pansy Tlakula (IEC 2005), announced that ' 9.2 million of registered voters, representing $44.47 \%$ of all registered voters, were youth voters' (between the ages of 18 and 35). These data cannot be compared with those recorded in 1999 and 2009 as there are no data for the age group 18-35; however, 43 per cent of youth actually voted in the 1999 election (Misra-Dexter 2009).

The increase in voter registration may not indicate increased political interest, it may merely reflect population growth (Kotze 2010, p 28). Similarly, in the absence of an exit poll, it is difficult to establish whether the high youth registration figures translated into an increase in the total number of young voters. If more than 23 million people registered to vote in the 2009 general election and only 17.9 million actually voted, more than 5 million registered but did not vote. The increase in the overall voting population may have had an impact on the increase in youth registration but not necessarily on turnout.

Table 2

National election data, 1994-2009

\begin{tabular}{|l|r|r|r|r|}
\hline & $\mathbf{1 9 9 4}$ & $\mathbf{1 9 9 9}$ & $\mathbf{2 0 0 4}$ & $\mathbf{2 0 0 9}$ \\
\hline Registered voters & & 18172751 & 20674926 & 23181997 \\
\hline Ballots cast & 19533498 & 16228462 & 15863558 & 17919966 \\
\hline Voter turnout & & $89.30 \%$ & $76.73 \%$ & $77.30 \%$ \\
\hline Valid ballots & 19340417 & 15977142 & 15612671 & 17680729 \\
\hline Spoilt ballots & 193081 & 251320 & 250887 & 239237 \\
\hline$\%$ spoilt & $0.99 \%$ & $1.55 \%$ & $1.58 \%$ & 1.34 \\
\hline
\end{tabular}

Source: Table compiled from data sources for each election listed by year (http:/ / electionresources.org/za/)

1 Documented correspondence detailing registered voters between age 18 -29 by election year for 1999, 2004 and 2009, between Zandile Bhengu and IEC official Brian Heuvel on 8 December 2009.

2 Ibid. 
Although there was a general increase in youth registration ahead of the 2009 elections and despite the fact that the polls indicated an increase in the number of young people who voted this cannot be used as a definite indication of a high youth voter turnout.

Interestingly, while voter registration has increased, Table 2 illustrates that voter turnout has decreased. The overall turnout for the national and provincial elections was $77.30 \%$ in 2009, compared to $76.73 \%$ in 2004, $87.9 \%$ in 1999 and $85.8 \%$ in 1994. The reason for the declining voter turnout may be found in South Africa's history. The 1999 election was only the second multiparty democratic non-racial election since the end of apartheid. This was a time of heightened political interest because of the dramatic changes sweeping through society, which could point to higher levels of political interest and thus voter turnout. Over the years people tend to lose interest in elections and government as the gap between them and the governments they elect widens.

A survey conducted by the Human Sciences Research Council (HSRC) in 2005 found that

age is a critical factor in the proportion of people that [are] registered as voters. Whereas over $90 \%$ of people aged 35 or older were registered, this is the case with only $86 \%$ in the $25-34$ year category. Most noticeable is the $49 \%$ level amongst the youngest (18-24) age group. More than half of the 18-24 year olds were thus not registered as voters.

HSRC 2005, p 14

A lack of interest in voting was cited as the main reason for the low registration rate in this (18-29) age cohort. This appears to indicate that interest in voting comes with maturity, since more people register as they approach their 30s. This view is confirmed by HSRC data from 2008 when it was found that:

the predominant reasons cited by 18-29 year-olds indicating that they will not vote are lack of interest. In the 18-29 age category 53\% cited a 'lack of interest in voting' as opposed to $17 \%$ who failed to register as voters, $16 \%$ who lacked an I.D. book and $11 \%$ who are disillusioned with politics.

Roberts \& Letsoalo 2009, p 12

\section{ELECTORAL PARTICIPATION AND DEMOCRACY}

Elections do not always contribute to the consolidation of democracy. Low youth turnout at polling stations should not necessarily be equated with politically 
inactive youth. It may mean that young people are not interested in formal electoral processes and structures. Elections in South Africa have not always been an indication of democracy. During apartheid only whites could vote, and later Indians and coloureds had a limited franchise in a tri-cameral parliamentary system with each chamber representing one race and the whole co-ordinated by a President's Council. Most Indian and coloured South Africans rejected or simply did not participate in this system, as evidenced by the 'extremely low turnout levels for tri-cameral elections' (South African History Online). The large scale rejection of the system of limited and qualified 'own affairs' franchise by Indians and coloureds and the continued disenfranchisement of Africans meant that the majority of the black population had no experience of electing a truly representative government. Despite this, they remained politically engaged and mobilised, with those in exile participating in underground politics and those inside the country taking politics to the streets and confronting the apartheid system.

The popular adage 'elections are not an end itself, but a means to an end' means there are other ways to enhance and enjoy democracy. Brigalia Bam, chairperson of the IEC asserted that 'voting is just a single note in an orchestra of democracy. Free and fair elections, freedom of expression, equality before the law and due process are all aspects of democracy that we should not forget' (IEC 2009c). In addition, the enjoyment of fundamental political and socio-economic rights, a vibrant vigorous civil society and a democratic politics that extends beyond the way in which a state is managed and administered lend themselves to instilling a substantive democratic culture rather than merely a formalist, procedural democratic system.

While the systemic aspects of democracy are important to young people, hence the clamour for inclusion in institutions, the democratic goods that make society a space for vibrant expression and contestation appear to be equally important. This does not necessarily mean that elections and the vote are not taken seriously.

'In successive elections, large numbers of citizens endured considerable inconvenience to vote in a context in which the results were a foregone conclusion, and in which there was therefore no instrumental rationale for bothering to vote' (Friedman 2005, p 765, citing Friedman 1999).

It can then be safely assumed that citizens voted because they wished to express themselves, not purely to serve an instrumental purpose. Voting then assumes a symbolic purpose, beyond that of its instrumental utility to achieve some electoral outcome or to procure access to certain goods and services. It is important in that it allows 
citizens to express themselves and is a significant indicator of the extent to which citizens view themselves as a part of the political process. It is, as is ordinarily understood, to be a mechanism for representation for citizens, and an opportunity for political parties to gain and fulfil the representative function in democratic institutions by winning seats in order to articulate the aspirations and interests of its constituents. The vote, or an election, amongst other things, is the first and most fundamental premise in any conceptualisation of a democracy.

Fakir 2007, p 17

As evidence below demonstrates, however, for young people a democratic vote is tied to the achievement of the instrumental purpose of finding youth representation in political office and in the claims that the youth wish to make on the state by seeing their demands reflected in policy. In addition, it appears that young people, as the evidence below suggests, expect to find other young people occupying executive positions in government institutions.

\section{THE YOUTH AND SOUTH AFRICA'S POLITICAL HISTORY}

Many interesting events which preceded the 2009 elections may have had a significant impact on socio-political dynamics in the country and on the aspirations, desires and needs of the youth.

During the apartheid era young people played a significant role in weakening the system and exposing its vulnerability. The youth became mobilised in the face of a 'new South Africa', spearheaded by the South African Youth Congress (SAYCO). As Straker (1992, p 19) argues, they 'saw themselves as leading the older generation to freedom'. The 1976 Soweto uprising is just one example of this.

Participation in the anti-apartheid struggle afforded young people (as well as their elders) the power to exert their vision of freedom, power and influence over their own lives. The ANC military wing, for instance, largely consisted of young people. Political participation was the norm and abstention was 'the exception rather than the rule' (Straker 1992, p 19). The political environment at the time demanded that young people render the system of apartheid ungovernable, especially in the 1980s. The dawn of democracy, however did not reward this group with the formal and socio-political space to participate in the construction of the post-1994 democratic governance system and its institutions.

The ANC-aligned Mass Democratic Movement, and the ANC in particular, drew its major support from three components, namely the ANC Youth League, the ANC Women's League (ANCWL) and the workers, under Cosatu's umbrella. 
The struggle yielded results for the women's league, with an equity quota on the ANC's electoral list, as well as other quotas for the representation of women in public as well as party positions. Currently, women occupy high positions in all branches of government.

There have been tangible benefits for workers, too. Their engagement in popular struggle has led to the introduction of a labour regulatory regime which sets out basic worker rights and benefits and introduces minimum wages. In addition, 'worker unions have played a strong role in deploying unionists as public representatives at all levels' (Sachs 2005). Unlike these sectoral constituencies, the youth, it can be argued, have not benefited to any great extent. Youth representation lags behind that of women and workers. Michael Sachs, a former researcher for the ANC, argues that it is not that the youth are apathetic about politics but rather that 'democratic institutions have failed to engage them, the youth have given expression to their profound optimism and energy by politicising the cultural sphere' (Sachs 2005).

Whatever the eventual turnout of the youth segment in the 2009 elections, registration was high, signalling some interest in the elections as an instrument of political contestation, an important indication that they are interested in participating in the formal process of democratic elections. However, data about participation derived from electoral processes and membership of union structures present a slightly different picture. At tertiary institutions levels of participation in elections for student councils, clubs and societies are quite low. By way of example, there was a turnout of 23 per cent in the 2009 student representative council (SRC) elections at the University of the Witwatersrand and 25 per cent at the Durban University of Technology. ${ }^{3}$ The low turnout is said to have been caused by the failure of the SRCs to transcend political rivalries and differences to represent all students no matter their political affiliations (IEC 2007a).

A survey conducted by the National Labour and Economic Development Institute indicates that 40 per cent of young workers do not belong to unions (Cosatu press statement 15 June 2010). More worryingly, 40 per cent of young people between the ages of 18 and 24 are not employed, studying, or in workplace training and are not affiliated to labour unions (Cosatu press statement 15 June 2010) or student unions or are likely to be members of other clubs and societies because of their limited access to post-matriculation education and employment opportunities.

This might, in part, serve to explain the participation of inordinate numbers of

3 e-mail correspondence between Zandile Bhengu and Bafana Nhlapo, SRC president at the University of the Witwatersrand, Johannesburg, 12 August 2010 and correspondence between Zandile Bhengu and Malusi Phakamani Nxumalo, SRC manager at the Durban University of Technology, 12 August 2010. 
young people in driving the increasingly violent protests and direct citizen action mushrooming across large parts of South Africa and may also serve to explain their low levels of membership of trade unions, clubs and societies as well as of political parties, all of which have traditionally served as agents of political and other forms of socialisation. The failure to socialise citizens, particularly young citizens, effectively has led to increasingly antisocial behaviour among the youth and, more particularly, to the inability of political parties, trade unions and clubs and societies to encourage young people to participate in formal political and decision-making processes.

These statistics may also be early indicators of a level of socio-economic differentiation among young South Africans. Those who are relatively privileged because of their access to education and upward social mobility might be opting out of political and electoral processes because those processes are perceived to be inefficient, passé and ineffective in catering to their needs. However, those who are relatively less privileged (or those who are privileged but rely on political connections for business and access to goods and services) remain keenly interested in the political process as it brings access to goods and services they would not receive were they not an intrinsic part of the political process.

During a Youth Day rally in Katlehong in June 2009 President Jacob Zuma stated that 'while the government was doing its best to improve the conditions of the youth, it was also the responsibility of young people to participate' (The Star, 17 June 2009). ANC Youth League (ANCYL) president Julius Malema challenged Zuma, saying it was time for the government to be more responsive to the challenges faced by the youth in exchange for the youth's participation and support. Malema further said that youth votes were explicitly given to Zuma in exchange for (or payment through) 'free education, quality jobs with proper salaries and better working conditions' (The Star, 17 June 2009).

On the occasion of youth day Malema, Zuma, and Helen Zille of the Democratic Alliance (DA) all focused attention on the formation of the National Youth Development Agency (NYDA), an amalgamation of the Umsobomvu Youth Fund and National Youth Commission. According to Malema, the predecessors of the NYDA 'were useless and served friends, boyfriends and girlfriends of those who occupied senior positions' (The Star, 17 June 2010). He implored the newly formed NYDA to 'open doors for young people' (The Star, 17 June 2010). Helen Zille had no such hopes for the NYDA, anticipating that it would repeat the mistakes of previous government youth initiatives. She, described it as a partisan political structure rather than an organisation committed to the development of all young people, stating that it was bound to 'perpetuate patronage schemes for ANC loyalists' (MailEGuardianonline, 16 June 2009). Zille further criticised the appointment of Andile Lungisa, deputy president of the ANCYL, as chairperson 
of the NYDA, as a fundamental mistake (Mail\&Guardianonline, 16 June 2009) which would serve directly to politicise a government structure intended to serve a public youth constituency rather than merely a politically partisan one.

While the ANCYL deputy president's position may, in practice, not compromise the agency's public service mandate, Zille's concern raises queries about perceptions of the separation of the ruling party from state structures and about the ability of a public agency to serve all the youth, irrespective of their political affiliations. The appointment of such a high-profile political office bearer to the chair of a government body raises the spectre of patronage being dispensed on a partisan basis. The consequences of such perceptions may be apathy among the youth generally, and especially among those who are not politically connected or members of the ruling party.

Turnout at a discussion on Youth and Electoral Democracy, in which participants were drawn from different youth organisations, was extremely low, a fact attributed to 'high disillusionment among the youth; lack of political knowledge; limited choices presented by political parties; alienation; and the unfortunate view that an individual vote does not make a difference' (IEC National Youth Dialogue 2008).

The young people who participated in the workshop refuted the idea that they are politically apathetic, arguing that their political ideas and opinions are not accommodated by political parties and state organs in a manner that is relevant (IEC National Youth Dialogue 2008).

The youth maintained that their level of participation in electoral democracy was, in part, affected by the voting age of 18 , which was perceived to be too high. It was suggested that the voting age should be reduced to 16 to stimulate youth participation at an early age. This suggestion derived from a belief that 'youth at this age have the capacity to formulate political views and decisions' (IEC National Youth Dialogue 2008). Other complaints were that political leaders appeared to be generally unaccountable, particularly to the youth, and that a narrowing political space inhibited free participation. Participants furthermore argued that the current electoral system of proportional representation limited their ability to select representatives because the responsibility was left to the parties, of which they were not necessarily members. They also raised concerns about service delivery, namely that it is difficult to stimulate young people to participate in elections if they see no possibility of change or of benefiting from democracy. It was acknowledged that it is crucial for government to be accountable to the electorate by delivering on its promises. Political parties were criticised for only engaging the youth at election time.

Political ideology no longer appears to drive the youth into joining youth organisations to the same extent that it may previously have done, which is a 
reflection of their changing attitudes and perceptions and, more importantly, of the failure of political organisations to address issues relevant to young people. Membership of youth movements has been viewed simply 'as a means of enhancing a young person's career or other prospects rather than as an opportunity to advance youth-driven ideas and policies' (IEC National Youth Dialogue 2008).

While a decline in participation in elections may indicate an absence of interest in formal political structures low turnout at the polls should not be used as a yardstick. Democracy takes different forms and there is clear evidence of youth participation in activities and initiatives that drive the policies governing young people. They are active in religious and environmental groups, which are part and parcel of a functioning civil society which caters to their needs and allows them to express themselves.

There is also considerable participation by young people in political parties. The ANCYL played a major role in ensuring the ascension of Jacob Zuma to the presidency of the ANC. Young people also played a key role in the Democratic Alliance's 2009 election campaign and have been at the forefront of calls for changes in the leadership and political culture of the Inkatha Freedom Party. These examples bolster the point made above that when the youth perceive themselves to have a direct stake in the outcome of a process their active participation tends to be high.

\section{INTERNATIONAL YOUTH VOTING TRENDS: THE IMPACT OF THE OBAMA CAMPAIGN}

Barack Obama's campaign and Obama's election as president may have influenced the South African youth vote. Prior to that election young voters were distanced from politics. In 2000 the American Political Science Association Taskforce on Civic Education emphasised the low participation of young people, maintaining that 'Current levels of political knowledge, political engagement, and political enthusiasm are so low as to threaten the vitality and stability of democratic politics in the United States' (Shea 2009). However, youth participation in the formal political setting changed dramatically in 2008, partly due to Obama's innovative campaigning methods.

The mass media are a significant force in modern culture and today's young South Africans have largely grown up in a mediated culture, constantly exposed to messages from a multitude of sources, among them television, billboards, and magazines. The Internet has become a dominating mass medium, combining the audio attributes of radio, the visuals of television and the depth of text. It is no surprise, therefore, that it is used as a significant tool in political campaigns. 
The Pew Internet \& American Life Project reported that 75 per cent of all Americans, or more than 147 million people, use the Internet. 'Among these are 91 per cent of people aged between 18 and 29' (Barron 2008). Obama, recognising the importance of the youth as agents of change, engaged them in the political sphere through e-mail, text messaging, Twitter and Facebook (through groups such as 'I was alive when Barack Obama was president' and 'Students for Obama', a strategy that resonated with them. Obama's message of hope, togetherness and belonging, proclaiming 'Yes we can', appealed to young voters, the majority of whom voted for the first time.

As Benoit \& Benoit (2005, pp 232-234) point out the Internet enables information to be passed on to voters without a media filter and it allows campaigns to respond quickly to charges from other campaigns. It also allows candidates to send personalised messages to voters and, through chat rooms and other networks, gives voters the chance to put their own personal stamp on campaign information. The Internet as a tool in elections thus allows increased agency for both voters and parties.

Vargas (2008) illustrates the reach the mass media gave Obama's campaign team:

- An e-mail list that boasted some 13 million addresses.

- More than one million people, mostly young, signed up for Obama's text messaging programme.

- On election day everyone who signed up for alerts in battleground states received three text reminders to vote.

- More than five million people, mostly youth, signed up as supporters of Obama on social network sites.

- More than five million clicked the ‘I Voted!' button on Facebook.

The innovative campaign evoked a renewed interest in politics among young people: 64 per cent of 18 to 24 year olds were first time voters, compared to just 11 per cent of all voters (Circle report 2008). In addition to providing Obama and other Democrats with strong support, young voters were unusually active during the campaign period. According to Pew's post-election survey of voters 28 per cent of young voters in battleground states said they had attended a campaign event; far more than any other age group.

\section{THE SOUTH AFRICAN CONTEXT}

The Obama campaign was driven largely by a combination of traditional campaign strategies and the use of new media technology and social media platforms, which 
have social penetration in the United States because of high connectivity rates. Apart from mobile phones, the same levels of connectivity do not apply to South Africa, where Internet access is still limited and costly. Indeed, 'statistics reveal that fewer than five million South Africans have access to the Internet' (Chutel 2009). The extent to which political parties used Obama-type campaign strategies to attract the youth vote and to spur young people to participate in the electoral process is worth considering.

Both print and broadcast media were active in covering election related issues leading up to the 2009 South African election. The two major national television stations, the South African Broadcasting Corporation (SABC) and eTV, dominated the electronic media, while the main print media included The Star, the Mail $\mathcal{E}$ Guardian, the Sunday Times, City Press and the Sowetan. Media play an important role in democracies. As Roskin (1996) argues, media should transmit and provide factual information, raise awareness and, to a large extent, educate and develop critical thinking among the public'. However traditional media outlets may no longer live up to this role. As Fakir, Letsholo \& Ngidi (2010, p 75) argue, 'technology has taken media to another level and that is a critical level where the youth operates. To target the youth for elections, more creativity is necessary.' The question is to what extent did the South African political parties themselves succeed in drawing in the youth innovatively?

Two significant changes in the communications environment, namely the widespread adoption of mobile telephony (Donner 2008), and the rise of social media (blogs, YouTube, Flickr, Facebook, Twitter, etc) mediated political participation during the 2009 elections, and appealed particularly to the youth. Between 2003 and 2008 the number of mobile phone subscriptions per 100 people increased from 35.9 per cent to 90.16 per cent compared to only an estimated 4.1 million internet users, fewer than 10 per cent of the population (International Telecommunication Union 2009). The lack of access to computers means many people access the Internet via their mobile phones. Kreutzer's survey (2009) of students in low-income high schools in Cape Town suggests that many young urban South Africans first accesses the Internet via their phones.

The ANC combined traditional campaign methods such as door-to-door and political rallies with new media outlets. For instance, it sent election updates to supporters who had signed up via their mobile phones. In the run-up to the 2009 elections the ANC announced that the National Prosecuting Authority had dropped criminal charges against Zuma, who was by then the ANC's presidential candidate, and encouraged supporters to visit the www.myanc.mobi website, a new mobile version of the party's 'traditional' social media portal, www.myanc. org.za. The mobi site encouraged visitors to 'Have your say. We are listening' (Walton \& Donner 2009, p 5). The ANCYL 'adopted an unofficial but effective 
mobile social network campaign in its drive to win over some of South Africa's 1.3 million youthful first-time voters, as did youth from the opposition party, COPE' (Walton \& Donner 2009, p 5).

The ANC's social media campaign on myanc.org.za and on Facebook, YouTube, 24.com, blogs, and Twitter aimed primarily 'to engage with people who aren't necessarily going to vote for the ANC (Speed 2009 in Walton and Donner 2009, p 5). Indeed, South Africa's roughly 4 million 'traditional' Internet users are not the ANC's primary constituency, but the mobile site certainly ensured a wider reach.

The ANC, DA and Cope set up Mig33 groups, which, working via mobile phones, allows instant messaging, sharing of photographs, public chatrooms and the uploading of individual profiles. It also has a 'stadium' feature which supports mass chats among up to 5000 individuals at one time. The ANCYL sent out messages to members about upcoming events, both virtual gatherings such as appearances by youth league leaders in the chat 'stadium' and messages to mobilise large crowds for rallies and meetings such as braais and parties associated with the ANC election campaign.

The Mig33 chat rooms were more popular than the ANC'S mobi site, perhaps because the youth are used to accessing the Internet on their phones. Mig33 was not used by the majority of ANC supporters but was successful in engaging a core group of young supporters (Walton \& Donner 2009, p 8). The ANC also targeted the youth through campaigns in schools during school hours (Fakir, Ngidi \& Letsholo 2010, p 104) and, together with the DA and Cope, used television advertising. Indeed, 'for the first time in SA television history political parties were allowed to campaign for the upcoming elections through TV advertisements' (Fakir, Ngidi \& Letsholo 2010, p 104). They also campaigned on trains to reach the wider public.

The DA and Cope focused on building complex 'Obama-esque' websites in addition to using Facebook, Twitter and YouTube. The mobile version of the DA's website (mobi.da.org.za) was not prioritised and thus largely excluded the youth.

The IEC also employed modern technology to attract more, especially new, voters. On its website features such as ' $\mathrm{X}$ for democracy' educated new voters about the steps to follow to register and vote. The bright colours gave the site life and made it more appealing to young people. Voters could also check their registration status on the website. Young people had a problem with long queues and this gave them a better option. Chief electoral officer Pansy Tlakula was reported as saying: 'We call on eligible voters to finalise their details. We are grateful that people are using our internet facility and call centre. We are pleading for patience as we deal with the high volume of visits and requests for information' 
(IEC 7 February 2009a). This shows that, although access to the Internet and new media is limited in South Africa, those who had that access appear to have taken advantage of it. It was reported that 'by Sunday of the last registration weekend, at midday, the IEC's website had recorded a total of 22079 hits while the SMS facility had received 29538 messages and 22848 callers had contacted the Call Centre to enquire about their registration status or at which station they should register' (IEC 8 February 2009b). By the end of the two-day registration weekend the IEC had received more than 68865 hits and the SMS facility 95010.

A number of the IEC's voter education initiatives focused on the youth. Apart from encouraging young people to vote as a means of exercising their 'constitutional rights and as a means to have their voices heard' (IEC National Youth Dialogue 2008) the IEC selected a number of youth celebrities as election ambassadors 'who travelled the length and breadth of South Africa, talking to the youth about the importance of voting' (IEC National Youth Dialogue 2008). This initiative broke new ground in that the youth were targeted as an important part of the electorate. It might have been another reason for their high interest in the elections.

Nonetheless, the medium used in an election campaign may be less important than the content of the campaign. The Obama campaign succeeded in getting millions of young Americans voting, but it may have had a limited impact on young South Africans. Akoth (2009) argued that 'Generation Y voters in Africa constitute the largest voting segment of the population, yet power still rests with the older generation which has consistently failed to connect with them.'

Young South Africans may also feel disengaged from the policy process because they feel marginalised. Thomas E Patterson, of Harvard's 'Vanishing Voter Project', points to the importance of issues and voter concerns in relation to voter registration and the casting of ballots. Referring to the USA he explains that 'historically [people] have voted in higher numbers when the nation confronts big issues. That was as true in the late 1800 s and 1930 s as it has been more recently. The meltdown in the financial markets [in the fall of 2008] likely confirmed Americans' belief that 2008 was a watershed election' (Patterson 2008). Putnam (2000, p 35) takes this point further:

Very little of the net decline in voting is attributable to individual change and virtually all of it is generational ... [Moreover,] declining electoral participation is merely the most visible symptom of a broader disengagement from community life. Like a fever, electoral abstention is even more important as a sign of deeper trouble in the body politic than as a malady itself. 
Consequently, the argument is that people are becoming increasingly individualised and unless issues are relevant to individuals those individuals may be largely apathetic about elections. Government has failed 'to create institutions that effectively champion the cause of the youth in such a way that their most basic aspirations assume the status of hegemony that informs and guides policy and practice of all the institutions of government and state' (Putnam 2000).

Young people were very active in the resistance to the apartheid system, took politics to the streets, and made apartheid unworkable because the system had a direct impact on their daily lives. The fact that this is no longer the case may explain why they now abstain from involvement in their schools, communities, and the nation. Another reason is that they may see formal political platforms as corrupt, ineffective, and unrelated to their deeper ideals.

However, as observed above, young people did register in relatively large numbers. Markinor's survey of interest in politics among different age groups found that 64 per cent of 18-24 year olds and 65 per cent of 25-34 year olds were very interested in politics' (Markinor 2002). A preoccupation of considerable relevance is unemployment, an issue the ANC used to attract young voters through its youth league website, featuring 'links to career guidance, youth in business and job listings such as BOSS, a database of youth-owned businesses' (Chutel 2009).

At the ANC's National General Council of 2000 it was noted that 'the youth in particular need to be mobilised behind the revolution, to which end resources must be directed at addressing issues such as high unemployment, which constrains the participation of the youth' (ANC 2000). The campaign appealed to the youth economically but did not mobilise them politically.

The ANC encouraged participation in the development of its policies and thus gave voice to its constituencies by 'inviting primarily its members, but also the public, to contribute ideas' to its manifesto (Fakir, Letsholo \& Ngidi 2010, p 77). 'In November 2008 the ANC launched a public manifesto entitled "My ANC; My Vision; My Future" which invited the public to submit suggestions about what the manifesto should contain through a website, cellphone short messages (SMSs), by letter or by telephone' (Fakir, Letsholo \& Ngidi 2010, p 77). Thus the youth could be involved at a thematic level and make sure that their voice was heard.

Cope largely failed to address the concerns of the youth and the DA's website did not differ from its manifesto, which concentrated on preventing the ANC from winning a two-thirds majority. It reminded the youth of its opposition status as a party that was not ready to rule by failing to address key issues such as HIV / AIDS, unemployment and crime, instead pinpointing the ANC's failures through its famous 'The Real ANC Today'. The other parties did not recognise the youth as pioneers and drivers of change and transformation - essentially as 
political agents - and this grave mistake now counts as a lost opportunity for parties which might have attracted young and new voters. Campaigns should move from their rigid ideological nature to be more specific about addressing major issues affecting the youth.

The argument advanced here is that young people in South Africa have not been given sufficient political space to participate in formal democratic institutions. Institutions have been created and policy frameworks put in place, but the youth have not been sufficiently empowered to engage in these structures. Not all young people belong to political organisations such as the ANCYL. The lack of youth representation at high political level has, to some extent, discouraged them from participating in formal democratic structures. However, this does not mean that they do not use other means provided by a democracy to shape their future. In South Africa, they have held their leaders accountable through civic organisations, in which youth participation has been continuous. Organisations such as LoveLife, which promotes a positive lifestyle and has been active in spreading messages about HIV-AIDS, drug abuse and teenage pregnancy among other issues, have been youth-driven.

\section{CONCLUSION}

The notable difference between the youth of South Africa before and after 1994 lies in the form of their political participation. Previously young people were very active in the resistance to apartheid, took politics to the streets, and made the system unworkable. The youth of today participate in protests at tertiary level, in community level protests and in cultural political expression. Young people may be less affiliated to political parties but they are not necessarily less political.

Levels of participation by young people in formal political structures have been associated with their limited knowledge of politics. The Afrobarometer election survey for 2008 shows that more than 83 per cent of people support the notion of educating the youth about politics, with more than 73 per cent suggesting that schools should lead this initiative. Although young voters were satisfied with the way the elections were run they were less satisfied with their overall voting experience. Could this be because the parties did not communicate information relevant to the youth?

When politics is characterised and dominated, as has been the case in South Africa since 2006, by intolerance and factional debate, it becomes meaningful only to politicians and interested observers, and appears to become irrelevant to the youth, who do not see how their participation helps to address the challenges they face.

Internationally, the period 1995-2005 saw a growing acceptance of the importance of youth participation in decision-making, and successful efforts 
to engage young people in the political process have led to improved policy formulation, adoption, implementation and evaluation. Young people appear to prefer issue-based activities and campaigns because they deal with topics that interest them. Political ideology no longer drives young people to join youth organisations as it has done in the past, which is a reflection of the changing attitudinal and perceptual nature of young people and, more importantly, of the failure of political organisations to interpolate the youth into their ideological and political platforms.

The 2008 presidential campaign in the US complemented traditional forms of campaigning with extensive use of new media technologies and social networking sites. Obama's campaign strategists seemed to have understood the importance of the youth as agents and organs of change and of the instruments they use to discuss these matters and tailored their campaign to accord with new modes of social interaction and media consumption. In addition to simply using the tools of youth the campaign message was crafted to resonate with young Americans. Obama's message of hope, togetherness and belonging, using the proclamation 'Yes we can', appealed to young voters, the majority of whom voted for the first time. The content of the Obama campaign and its social penetration were more important than the medium used to communicate the message and managed to reach out to ordinary American who were interested in a change in the economy and in policy.

In Africa, though, where 'generation $Y$ voters ... constitute the largest voting segment of the population, ... power still rests with the older generation which has consistently failed to connect with them' (Akoth 2008).

It is widely assumed that the Obama election campaign had an impact on the decision by young South Africans to vote. This direct attribution can be questioned on the basis, firstly, that registration may not have translated into voting. Secondly, that 'intention' to vote as an indicator of increased interest in participation is undermined in part by the demonstration that the assumed increased interest among the youth may be attributable to factors such as a consequence of the coming of (voting) age of the 1990 generation, a rise in population growth, the drive to change the democratic trends of the country's politics and the need to reverse the inequalities which affects them.

An important factor that might have been overlooked in assessing the reasons behind the high youth voter registration and (moderately high) turnout is that young South Africans have always been politically active but have expressed themselves in ways that do not always conform or restrict themselves to the formal and procedural processes of decision-making. The youth have played a major role in what appear to be continuing social protests and what has been termed xenophobic violence in South Africa in 2008, in fact, they appeared to have been 
driving these protests. They have also been active in challenging the management of tertiary institutions. Youth activism cannot, therefore, be measured solely in terms of the participation of young people in the elections, there are other preferred means of participation which are less formal and driven by political ideology.

Citizens vote to express themselves, but parties largely failed to communicate messages that are of concern to the youth. Despite great efforts by the parties, particularly the ANC Youth League, through the use of new media technology, to include young people in the political process and thus encourage young voters, the future of youth participation in elections in the country is imperfect. A comparison of data on population growth, the number of youth eligible to vote and the number of those who registered has challenged the glib pronouncements that the interest and participation of the youth in the 2009 elections increased tremendously.

If young people are to be persuaded to participate in greater numbers it seems that what may be needed is dedicated strategies targeting them on the basis of racial and socio-economic differentiation. Parties may need to craft more relevant messages which resonate with the concerns of the youth, while appointments to government institutions should reflect the youth demographic where possible. More importantly, policy must be designed and implemented that is youth focused and non-partisan rather than based on patronage.

\section{- REFERENCES}

African National Congress (ANC). 1996. The State and Social Transformation: A Discussion Document. Available at: www.anc.org.za/ancdocs/policy/s\&st.html

- 2000. Report of the National General Council, Port Elizabeth. Available at: www. anc.org.za/ancdocs/ngcouncils/ docs2000/ finalreport.html

Akoth, D. 2009. Obama Should Inspire Africa's Generation Y. Nairobi: ISS.

Barron, R M. 2008. Master of the Internet: How Barack Obama Harnessed New Tools and Old. Lessons to Connect, Communicate and Campaign his Way to the White House. University of North Carolina at Chapel Hill, School of Journalism and Mass Communications Global Impact of New Communication Technologies. Available at: web.cs.swarthmore.edu/ turnbull/cs91/f09/ paper/barron08. pdf

Benoit, PJ \& W L Benoit. 2005. 'Criteria for evaluating political campaign Webpages'. Southern Communications Journal.

Cosatu. 2010. 'COSATU commemorates Youth Day'. Press statement, 15 June.

Circle report. 2008. Available at: www.civicyouth.org/turnout-by-education-raceand-gender-and-other-2008-youth-voting-statistics / 
Chutel, L. 2009. 'Attracting the youth vote'. Diplomatic Pouch. Johannesburg: SAIIA, 27 May. Available at: www.saiia.org.za/diplomatic-pouch/attracting-theyouth-vote.html

Donner, J. 2008. 'Research approaches to mobile use in the developing world: A review of the literature'. The Information Society 24(3).

Donner, J \& S Gitau. 2009. 'New paths: exploring mobile-centric internet use in South Africa'. Paper presented at the Pre-Conference on Mobile Communication at the Annual Meeting of the International Communication Association. Available at: lirneasia.net /wp-content/uploads/2009/05/final-paper_ donner_et_al.pdf

Fakir, E. 2007. 'The Nexus between Democracy and Development'. Address delivered to a Multi- Stakeholder Conference: Reflections on the State of Electoral Democracy in South Africa, 8-10 October, The Forum, Bryanston. Available at: www.elections.org.za/MultiStakeholderConference/ DocumentView.aspx

S Letsholo \& N Ngidi. 2010. 'Gauteng: Electoral Performance of Parties in the Province 2004'. EISA Election Update South Africa Feb-July 2009. Johannesburg: EISA.

Fakir, E, N Ngidi \& S Letsholo. 2010. 'Gauteng'. EISA Election Update South Africa Feb-July 2009. Johannesburg: EISA.

Friedman, S. 1999. 'Who We Are: Voter Participation, Rationality and the 1999 Election'. Politikon, South African Journal of Political Studies 26(2).

— 2005. 'Getting Better Than "World Class": The Challenge Of Governing Post-Apartheid South Africa'. Social Research 72(3), Fall.

Government Gazette. 2008. 'National Youth Policy 2008-2013'. Pretoria; Government Printers, 17 December.

HSRC Socio-Economic Surveys Unit of the Knowledge System Group. 2005. 'Identity Documents and registration to vote'. Prepared for The Independent Electoral Commission.

— 2009. 'The results of the 2008 Voter Participation Survey Commissioned by the IEC', 2 February.

IEC. 2005. Report on the National and Provincial Elections of 14 April 2004. Pretoria: IEC.

2007a. Report of the proceedings of the SRC Colloquium: Enhancing Sustainable Electoral Democracy Development in Higher Education. Colloquium held at Kopanong Conference Centre, Benoni, Gauteng, 1-4 April.

—. 2007b South African Voter Registration Case Study, 24 October 2007.

- 2008. The Role of the Youth in Electoral Democracy in South Africa. Report of the proceedings of the IEC's National Youth Dialogue on Electoral Democracy, held at the Midrand Conference Centre, Gauteng, 30 October. 
—. 2009a. 'Chasing 22 million eligible voters by Election Day'. Pretoria: IEC, 7 February.

— 2009b. 'IEC buoyant on final weekend registration drive'. Pretoria: IEC, 8 February.

-2009c. 'IEC announces final results in South African poll'. Available at: www. elections.org.za/news_get.asp?press $=0 \& N e w s I D=420 \& O p t=\& D a t a=\& R e c$ Num=21, 25 April.

International Telecommunication Union (ITU). 2009. Online statistics, ICTeye. Available at: www.itu.int/ITU- D/icteye/Indicators/Indicators.aspx

Kotzé, D. 2010. ‘Party Political Contestation and Configuration of Power: Likely Scenarios of the Election Outcome'. EISA Election Update South Africa Feb-July 2009.

Kreutzer, T. 2009. 'Generation Mobile: Online and Digital Media Usage on Mobile Phones Among Low-Income Urban Youth in South Africa'. Master's thesis University of Cape Town. Available at: www.tinokreutzer.org/mobile/ MobileOnlineMedia-SurveyResults-2009.pdf

Levin, M. 2000. 'Opting out of Organised Politics: Youth and the Elections (Development Update'). Interfund/SANGOCO 3(2).

Mail\&Guardianonline. 2009. 'DA expresses concern over youth agency'. Available at: www.mg.co.za/article/2009-06-16-da-expresses-concern-over-youthagency

Markinor. 2002. Socio and Political Trends, November.

Misra-Dexter, N. 2009. Election Brief: The Youth Vote. IDASA, 21 April.

National Youth Commission. 2002. Status of the Youth Report. Pretoria: SABC/ Markinor.

Ngobese, C. 2009. 'Invitation to chat with WCLSANational Secretary Buti Manamela 20 April'. Press release. Available at: groups.google.com/group/yclsa- press/ browse_thread/thread/a045aab36ad6fa7f?pli=1

Opinion. 2003. 'Interest in politics and elections'. Press statement, 17 July.

Patterson, T E. 2008. 'Voter turnout approaches some records, breaks others'. Harvard Gazette, 6 November.

Putnam, R. 2000. Bowling Alone: The Collapse and Revival of American Community. New York: Simon and Schuster.

Roberts, B \& T Letsoalo. 2009. 'The young and the restless: Political apathy and the youth'. HSRC Review 7(1), April.

Roskin, M G. 1996. Political Science: An Introduction. Engelwood Cliffs, New Jersey: Prentice-Hall.

South African History Online. 2005. 'Civil Society Protest 1980s. The trigger of mass civil society protests in the 1980s: 1983 Tricameral Parliament'. Available at: www.sahistory.org.za/ classroom/grade12/3-3-1-1.htm 
Sachs M. 2005. 'Youth and politics in the democratic order'. Umrabulo, Journal of the African National Congress 23, 2nd Quarter 2005.

Shea, D M. 2009. 'Young Voters, the Obama Net-roots Campaign, and the Future of Local Party Organizations'. Paper prepared for the 'State of the Parties Conference', University of Akron, 16 October.

Star, The. 2009. 'Malema: "Zuma owes youth"', 17 June 2009.

StatsSA. 2001. 'The Youth of South Africa: Selected Findings from Census '96'. Available at: www.info.gov.za/view/DownloadFileAction?id=70309

- _ 2009. 'Mid-year population estimates, Table 16. Provincial Population Estimates by Age and Sex'. Pretoria: StatsSA, 27 July. Available at: www.nmc. gov.za/Docs/MidYearEstimates2009.pdf

Straker, G. 1992. Faces in the Revolution: The Psychological Effects of Violence on Township Youth in SA. Cape Town: David Philip.

Strom, M-L. 'Democracy: More than elections'. Youth Vote South Africa 4.

United Nations. 2000. 'The World Programme of Action for Youth to the Year 2000 and Beyond'. Available at: www.un.org/events/youth98/backinfo/ ywpa2000.htm

Vargas, J A. 2008. “'Obama Raised Half a Billion Online”: Politics and Policy in Obama's Washington Series'. The Washington Post. Available at: voices. washingtonpost.com/44/2008/11/ obama-raised-half-a-billion-on.html

Walton, M \& J Donner. 2009. ‘Read-Write-Erase: Mobile-mediated publics in South Africa's 2009 elections', 9 October 2009. Available at: jonathandonner.com/ readwriteerase_prepub.pdf

World Youth Report. 2005. Global Trends, Youth in Civil Society. 